\title{
Cholera Control is an Urgent Issue
}

\author{
Sujit K Bhattacharya* and Sabahat Azim \\ Glocal Healthcare Systems Private Ltd, India
}

Submission: September 21, 2017; Published: October 20, 2017

*Corresponding author: Sujit K Bhattacharya, Glocal Healthcare Systems Private Ltd, Ecospase, Kolkata, India, Tel: +8697462003;

Email: sujitkbhattacharya@yahoo.com

\section{Opinion}

Cholera is known to mankind from ancient times as a killer. Although Pacine from Italy discovered Vibrio cholerae, but his discovery was over shadowed by Robert Koch who in 1884 rediscovered Vibrio cholerae from the fecal samples of patients suffering from acute watery diarrhea. Cholera causes acute watery diarrhoea, vomiting and life-threatening dehydration in the absence of fever and abdominal cramps. Cholera can cause asymptomatic infection to mild and moderate diarrhoea or severe diarrhoea. Vibrio cholerae is the responsible etiologic agent of the disease. The bacterial agent can be divided into 01 Eltor, 0139 Bengal and classical types. All of them produce an exotoxin called cholera toxin (CT) which is responsible for the pathogenesis of the diseases. It is a fecal oral route transmissible disease. The disease can occur as asymptomatic infection, sporadic diarrhoea, outbreaks (epidemics) and even pandemics. The current pandemic is the $7^{\text {th }}$ pandemic which swept through more than 102 countries worldwide. The epidemic started from the Celebes island of Indonesia in 1961.

An unprecedented epidemic appeared from Vellore, India in 1992 and almost simultaneously in Kolkata, India and Dhaka, Bangladesh. The causative agent responsible was found to be Vibrio cholerae 0139 Bengal because it was isolated from the Gangetic delta. 0139 cholera is similar to Eltor cholera and clinically indistinguishable from each other [1]. The epidemic spread to many parts of the Globe and Scientists thought that this is the beginning of the $8^{\text {th }}$ pandemic of cholera. Cholera Vibrio is an elusive micro-organism and the Scientists were proved wrong when the epidemic did not spread worldwide.

We may recall that cholera toxin (CT) was shown to be an exotoxin in rabbit ilea loop by Professor S. N. De, a medical teacher in one of the Kolkata (the then Calcutta) Medical Hospitals. His epoch making discovery and others, the pathogenesis of cholera was elucidated. This discovery also paved the way to the development of Oral Rehydration Salt Solution (ORS), which saved the life of millions of children all over the world. The results of these discoveries convinced world Health Organization to launch the Control of Diarrheal Disease Programmed (CDD). ORT corners were set up in various hospitals. Saved the lives, but did not prevent cholera. So the battle continued.

The traditional control measures as recommended by WHO includes sanitation, safe water and personal hygiene. These measures are long term goals and there remains something more to be done. Are vaccines a suitable supplement! Inject able cholera vaccine was developed, but because of its reactogenicity, it was discarded. A number of studies indicated that Oral cholera Vaccine (OCV) may be more effective than the Inject able vaccine. Recently, an oral cholera vaccine has been developed. This vaccine was effective $(66 \%)$ in preventing cholera for 5 years [2]. OVC can be used for prevention of endemic and epidemic cholera.

Cholera is a disease of poverty, poor sanitation, hygiene and overcrowding. OCV is an interim measure. Therefore, the battle against cholera remains a top priority since it affects about 1.3 to 1.4 million cases and 21 to 143 millions of deaths worldwide. Community participation, Governmental support, NGO initiatives, political will and resource mobilization are some of the suggested measures which can trigger fight against cholera and foster economic growth.

\section{References}

1. Bharati K, Bhattacharya SK (2014) Cholera outbreaks in South-East Asia. Curr Top Microbiol Immunol 379: 87-116.

2. Bhattacharya SK, Sur D, Ali M, Kanungo S, You YA, et al. (2013) 5 year efficacy of a bivalent killed whole-cell oral cholera vaccine in Kolkata, India: a cluster-randomised, double-blind, placebo-controlled trial. Lancet Infect Dis 13(12): 1050-1056. 


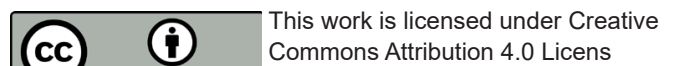

(C) DOI: 10.19080/AIBM.2017.06.555697

\section{Your next submission with Juniper Publishers} will reach you the below assets

- Quality Editorial service

- Swift Peer Review

- Reprints availability

- E-prints Service

- Manuscript Podcast for convenient understanding

- Global attainment for your research

- Manuscript accessibility in different formats ( Pdf, E-pub, Full Text, Audio)

- Unceasing customer service

Track the below URL for one-step submission https://juniperpublishers.com/online-submission.php 